\title{
O DIREITO ADMINISTRATIVO DISCIPLINAR NA POLÍCIA CIVIL DO ESTADO DE SÃO PAULO
}

\author{
MARCOS DE LIMA PORTA*
}

\begin{abstract}
Introdução. - O Direito Administrativo Disciplinar. 1 - $O$ Direito Administrativo Disciplinar Substantivo. 1.1 - Considerações iniciais. $1.2-A$ atividade administrativa disciplinar. 1.3 - Os ilícitos administrativos: disciplinares e funcionais. $1.4-A$ penalidade administrativa. $2-O$ Direito Administrativo Disciplinar Adjetivo. 2.1 - Introdução. 2.2 - Os processos administrativos disciplinares no âmbito da Polícia Civil do Estado de São Paulo. Conclusão. Referências bibliográficas.
\end{abstract}

\section{Introdução}

Apesar de o Direito ser uno e indivisível, desde os antigos romanos já se fazia a separação do Direito em público e privado. ${ }^{1}$ Isso ocorre porque cada um desses ramos possui um regime jurídico próprio e peculiar, que os diferencia.

O conteúdo jurídico do direito público é constituído por normas que revelam a predominância do interesse público, estando voltadas diretamente para regular os interesses da coletividade e reflexamente os indivíduos. Já as normas jurídicas que fazem parte do direito privado estão voltadas para regular os interesses dos particulares. Há, portanto, uma diversidade de interesses, que impõem tratamentos jurídicos diferentes.

* O autor é Juiz de Direito Estadual/SP, professor, mestre e doutorando em Direito do Estado, sub-área de concentração: Direito Administrativo, pela Pontifícia Universidade Católica de São Paulo.

1 Na lição do Prof. Oswaldo BANDEIRA DE MELLO: "A posição adotada para distinguir o direito em público e privado se filia, em última análise, a assumida pelo Direito Romano em conhecido fragmento de ULPIANO, no Digesto, I, 1, 1.2, e repetida nas Institutas de Justiniano, I, 1.4" (Princípios gerais de direito administrativo, 2" ed., Rio de Janeiro: Editora Forense, 1979, p. 27 , v. 1). 
Mas não é só desse prisma que se justifica a separação do Direito. Também há razões pedagógicas e políticas. A divisão faculta o estudo do próprio Direito e permite que se vislumbrem "princípios informadores do tipo de Estado com referência à vida social, para assegurar a ordem pública, e os bons costumes vigentes, segundo a cultura do povo - a sua inderrogabilidade pelas partes". ${ }^{2}$

Fixada a separação do Direito em público e privado, interessa verificar onde está alojada a disciplina designada direito administrativo e qual é o seu regime jurídico.

A Constituição Federal é o principal diploma jurídico pátrio. Ela adota, entre outras, as teorias da divisão funcional dos Poderes e do Estado Democrático de Direito. ${ }^{3}$ Uma das conseqüências desses postulados jurídicos é a possibilidade de se verificar em um conjunto de normas e princípios jurídicos a existência de um peculiar sistema que adquire identidade e que foi designado de Direito Administrativo. ${ }^{4}$

Essa disciplina jurídica pode conceituar-se como "o ramo do direito público que tem por objeto os órgãos, agentes e pessoas jurídicas administrativas que integram a Administração Pública, a atividade jurídica não contenciosa que exerce e os bens de que se utiliza para a consecução de seus fins, de natureza pública" ; ${ }^{5}$ ela está submetida a um regime jurídico-administrativo cuja base está firmada em dois grandes princípios, a saber: a) a supremacia do interesse público sobre o particular; e $b$ ) a indisponibilidade do interesse público pela Administração Pública.

O primeiro deles constitui uma prerrogativa da Administração, que é erigida pelo ordenamento jurídico numa posição de prevalência e de autoridade quanto às demais relações. Ou, no dizer do Prof. Antônio BANDEIRA DE MELLO:

"Trata-se de verdadeiro axioma reconhecível no moderno Direito Público. Proclama a superioridade do interesse da coletividade, firmando a prevalência dele sobre o do particular, como condição até mesmo, da sobrevivência e asseguramento deste último.

É pressuposto de uma ordem social estável, em que todos e cada um possam sentir-se garantidos e resguardados.".

Disso resulta para a Administração, por exemplo, a existência de prazos especiais para contestar, ou até mesmo recorrer das decisões judiciais.

O segundo consiste na impossibilidade dessa Administração Pública de agir sem o amparo da lei, a qual acaba conferindo por intermédio do Direito, a indisponibi-

2 Ibid., p. 30.

3 Arts. $1^{\circ}$ e $2^{\circ}$ da Constituição Federal.

4 Ou como afirma o Prof. CELSO ANTÔNIO Bandeira de Mello: "Diz-se que uma disciplina jurídica autônoma quando corresponde a um conjunto sistematizado de princípios e normas que lhe dão identidade, diferenciando-a das demais ramificações do direito" (Curso de direito administrativo, São Paulo: Malheiros, 1996, p. 23).

5 Maria Silvia Zanella DI PIETRO. Curso de Direito Administrativo, São Paulo: Malheiros, 1999, p. 52).

6 CELSO ANTÔNIO Bandeira de Mello, Curso..., p. 27. 
lidade do interesse público, isto é, acaba impondo à Administração a necessidade de observância, quando da sua atuação dos chamados direitos dos administrados. Nessas condições, os agentes públicos jamais abrirão mão do interesse público e deverão atender, em consequiência, os princípios da legalidade, igualdade, publicidade, moralidade administrativa, entre outros princípios ou subprincípios, explícitos ou implícitos, no ordenamento jurídico.

\section{O Direito Administrativo Disciplinar}

Por razões didáticas ${ }^{7}$ é possível também visualizar a construção sistemática de um sub-ramo do Direito Administrativo designado de Direito Administrativo Disciplinar.

Ele se configura por intermédio de um conjunto de regras e princípios que se atraem, adquirem coesão e que gravitam em torno de um núcleo fundamental comum consistente na necessidade e do interesse de se aperfeiçoar progressivamente o serviço público, no âmbito interno da Administração Pública. ${ }^{8}$

Nesses termos, afastam-se as relações jurídicas que se encontram no âmbito externo da Administração Pública porque tratadas por outros sub-ramos do Direito Administrativo, por exemplo, pelo Direito Administrativo Sancionatório; ${ }^{9}$ ainda, é possível verificar a existência de dois sentidos de abrangência do Direito Administrativo Disciplinar: um sentido amplo que abrange todos os agentes públicos ${ }^{10} \mathrm{e} u m$ sentido estrito que somente abrange os servidores público. ${ }^{11}$ Em razão do objeto de estudo deste trabalho, adota-se o sentido estrito de abrangência do Direito Administrativo Disciplinar, isto é, tão-somente os servidores públicos civis que compõem os quadros da Polícia Civil do Estado de São Paulo.

7 O Prof. Egberto MAIA LUZ averba ainda que: "Em síntese, o reconhecimento da existência do Direito Administrativo Disciplinar não decorre da evolução natural do Direito Administrativo do qual se teria desprendido, mas de sua própria essência, que não pode mais deixar de estabelecer a função normativa disciplinar que lhe é própria, destacando-a dos dispositivos legais, genéricos, relativos à participação do homem nas atividades administrativas oficiais" (Direito Administrativo Disciplinar, $2^{2}$ ed., rev. e atual, São Paulo: Editora Revista dos Tribunais, 1992, p. 65).

8 Cf. Hely Lopes MEIRELLES, Direito Administrativo Brasileiro, 23ª. ed., São Paulo: Malheiros, 1998, p. 109.

9 Cuja noção mistura-se com a expressão Administração Ordenadora que se configura pelas seguintes características: "a) trata-se de exercício de função administrativa; b) voitado à organização da vida privada; c) dentro de relação genérica; d) com a utilização do poder de autoridade" (Carlos Ari SUNDFELD, Direito Administrativo Ordenador, $11^{2}$ ed., São Paulo: Malheiros, 1997, p. 20). 10 Neste trabalho adota-se a classificação do Prof. CELSO ANTÔNIO Bandeira de Mello sobre os agentes públicos. Para esse autor os agentes públicos são gênero, cujas espécies são: a) agentes políticos; b) servidores estatais e servidores das pessoas governamentais de Direito Privado; c) particulares em colaboração com a Administração (Curso de Direito Administrativo, $13^{a}$ ed., São Paulo Malheiros, 2001, p. 226 a 306).

11 Nesse sentido, ver Romeu Felipe BACCELAR FILHO, Princípios Constitucionais do Processo Administrativo Disciplinar, Sāo Paulo: Max Limonad, 1998, p. 32. 
Para que o objetivo do Direito Administrativo Disciplinar possa ser atingido na Administração - na qual se inclui a Polícia Civil do Estado de São Paulo - deve adotar, no desenvolvimento de suas atividades administrativas, uma desejável disciplina, resultante das regras jurídicas estabelecidas, que descrevem condutas e impõem sanções.

Enquanto não há lesão a essa ordem jurídica vigente esse dever disciplinar previne os ilícitos administrativos e faz com que a Administração cumpra o seu verdadeiro papel, isto é, de satisfazer direta, concreta e de imediato os interesses públicos primários da coletividade. Porém, quando ocorre qualquer lesão à ordem jurídica e há, em consequiência, a ruptura da disciplina, cabe à própria Administração o dever de restabelecer a ordem jurídica violada; para isso, deve agir com repressão contra o seu infrator representada pela imposição de uma penalidade administrativa. Nasce daí, pois, para a Administração, o jus puniendi administrativo em relação aos servidores públicos civis faltosos, no caso, aqueles pertencentes aos quadros de pessoal próprios da Polícia Civil do Estado de São Paulo.

$O$ direito de punir, os ilícitos administrativos e as penalidades administrativas, por fazer parte da essência da ciência administrativa disciplinar, compõem o chamado direito administrativo disciplinar substantivo. O meio pelo qual se canaliza, externa e formalmente, a declaração estatal disciplinar é o processo administrativo disciplinar ${ }^{12}$ que compõe o Direito Administrativo Disciplinar Adjetivo.

Essa dicotomia será, a seguir, melhor analisada.

\section{1 - o Direito Administrativo Disciplinar Substantivo}

\section{1 - Considerações iniciais}

A Administração Pública, no caso desse estudo a Polícia Civil de São Paulo, tem o dever constitucional de exercer, principalmente, a atividade-fim de polícia judiciária. ${ }^{13} \mathrm{O}$ razoável desenvolvimento e o aperfeiçoamento dessa atividade depende de uma adequada organização administrativa que se sustenta por intermédio dos poderes administrativos entre os quais se encontra o poder administrativo disciplinar. A sua noção jurídica consiste no exercício de uma atividade administrativa que se inicia em razão da ocorrência de uma lesão a um ilícito administrativo gerada por um agente público, e que vai terminar com a possibilidade de se ter um resultado final punitivo, isto é, a possibilidade de ser aplicada uma penalidade administrativa. Essas três esferas jurídicas - a atividade administrativa disciplinar, os ilícitos administrativos (disciplinares e funcionais) e a penalidade administrativa - sintetizam o Direito Administrativo Disciplinar substantivo e que serão objeto de estudo dos próximos tópicos.

12 Expressão aqui empregada desprendida de maiores rigorismos científicos.

13 Ver art. 144 da Constituição Federal. Ainda, o art. $3^{\circ}$, inciso I, da Lei Complementar n. $207 / 79$ estabelece que: "São atribuições básicas: I - da Polícia Civil: o exercício da Polícia Judiciária, administrativa e preventiva especializada". 
O Direito Público tem o dever como eixo metodológico ${ }^{14}$ o que legitima dizer que toda a atividade estatal tem uma finalidade estabelecida pelo próprio Direito. No campo do Direito Administrativo vê-se que essa atividade configura-se numa função estatal, especificamente, administrativa, pois, por intermédio do ordenamento jurídico vigente, é imposto a um determinado agente público o dever de alcançar uma determinada finalidade legal. Essa atividade administrativa está adstrita, pois, à finalidade legal, inexistindo qualquer espaço para a autonomia de vontade, havendo, em razão do papel do próprio Direito Administrativo o dever inexorável de alcançá-la. ${ }^{15}$

O Direito estabelece funções administrativas heterogêneas. Para este estudo interessa a função administrativa disciplinar que consistente no dever de agir do agente público competente, imposto pelo próprio Direito, para restabelecer a disciplina interna violada, da própria Administração, em razão de ter havido uma infração administrativa praticada por um servidor público civil. Essa atividade administrativa disciplinar situa-se no plano da infralegalidade e está, pois, a serviço do Direito Administrativo Disciplinar.

Nesses termos, no âmbito da Polícia Civil do Estado de São Paulo as normas jurídicas ${ }^{16}$ que apontam esses agentes competentes e atribuem a eles o exercício da função administrativa disciplinar estão descritas, basicamente, em cinco diplomas jurídicos, a saber, as Constituições Federal e Estadual, a Lei Orgânica da Polícia do Estado de São Paulo (Lei Complementar n. 207/79), o Estatuto dos Funcionários Públicos do Estado de São Paulo, e, finalmente, a Lei Estadual n. 10.177/98, que regula o processo administrativo no âmbito da Administração Pública Estadual. Desses, destaca-se a Lei Orgânica da Polícia do Estado de São Paulo (Lei Complementar n. 207/79) por ser o diploma jurídico específico da Polícia Civil de São Paulo e que está possibilita o adequado estudo do tema deste trabalho. Além disso, ele revela com objetividade e clareza os agentes competentes e a própria atividade administrativa disciplinar, entre outras.

Segundo esse diploma jurídico, vê-se, pois, no art. 87 que a autoridade pública que detém a competência para exercer a função administrativa disciplinar, mediante sindicância ou processo administrativo, para a apuração de infrações administrativas praticadas pelos servidores públicos civis pertencentes aos quadros da Polícia Civil do Estado de São Paulo é o Delegado de Polícia. Esse agente público, por força do ordenamento jurídico vigente, detém o monopólio dessa espécie de atividade administrativa que se configura como disciplinar. Em razão da natureza dessa atividade,

14 Ver CELSO ANTÔNIO Bandeira de Mello. Discricionariedade e Controle jurisdicional, São Paulo: Malheiros Editores, 1992, p. 15.

15 Nesse sentido, por exemplo, é o artigo 90 da Lei n. 10.177/98.

16 Aqui entendidas por intermédio de seus elementos: i) a hipótese; ii) o mandamento; e, iii) a sanção. 
por mais que não queira, o Delegado de Polícia deve agir e aplicar a lei de ofício, exercendo o papel que lhe é atribuído pelo sistema jurídico vigente.

Todavia, em relação à aplicabilidade de sanção administrativa, o art. 70 dessa mesma Lei, estabelece uma variedade de agentes públicos competentes. Eles serão determinados segundo "a natureza, a gravidade, os motivos determinantes e a repercussão da infração, os danos causados, a personalidade e os antecedentes do agente, a intensidade do dolo ou o grau de culpa" (art. 69 da LC 207/68).

Portanto, o ordenamento jurídico vigente fixa o agente competente e estabelece a função administrativa disciplinar, inclusive no âmbito da Polícia Civil do Estado de São Paulo. Essa função constitui-se num dever de agir e desenvolve-se para um determinado fim, isto é, o ato administrativo disciplinar final, que também compete à Lei a fixação do agente para a sua extroversão, que varia, caso a caso, também em relação à Polícia Civil Estadual, por força da Lei Orgânica em vigor.

\section{3 - Os ilícitos administrativos: disciplinares e funcionais}

Para que o agente competente possa punir ${ }^{17}$ um servidor público civil, que se submete ao seu regime jurídico hierárquico e disciplinar, deve-se verificar se esse servidor é o responsável pela lesão à ordem jurídica vigente, formada por regras jurídicas que prevêem condutas que ora se referem a deveres e ora se reportam a proibições, além da culpabilidade.

Esses deveres e proibições são espécies de ilícitos administrativos designados pela doutrina de ilícitos disciplinares e ilícitos funcionais. ${ }^{18} \mathrm{~A}$ diferença entre eles está no fato de que, nos primeiros, a falta administrativa decorre de uma relação hierárquica; nos segundos, a falta administrativa "está capitulada como ilícito administrativo nas normas legais ou regulamentares, mas nada tendo a ver com a relação hierárquica entre subordinante e subordinado" ${ }^{19}$

Nesses termos, em relação aos servidores públicos civis pertencentes ao quadro de pessoal da Polícia Civil do Estado de São Paulo os ilícitos administrativos

17 Ontologicamente, esse direito de punir administrativo é o mesmo que o direito de punir previsto no Direito Penal. Ambos visam prevenir quando não há lesão, e repreender, quando há lesão à ordem jurídica vigente. Há, pois, uma afinidade ontológica entre essas duas esferas jurídicas. Porém, em razão do regime jurídico vigente - portanto, em razão do interesse puro e simples do legislador pátrio - , inexoravelmente verificam-se diferenças entre esses dois jus puniendi estatais, a saber: i) na esfera criminal esse direito de punir é exclusivo do órgão jurisdicional enquanto que o direito de punir administrativo é próprio da Administração; ii) a repercussão no Direito é maior em relação à prática de ilícitos penais do que dos ilícitos administrativos.

18 Ver nesse sentido a classificação do Prof. Edmir Netto de ARAÚJO: "Em suma, o ilícito administrativo poderá: a) configurar também um ilícito penal, como p.ex., o abandono de cargo; b) configurar apenas ilícito administrativo puro, nada tendo de penal, dividindo-se sempre em ilícito administrativo disciplinar (como p.ex., a desobediência a ordem legal de superior hierárquico) e ilícito administrativo não disciplinar (como p. ex., o exercício de comércio dentro da repartição) que preferimos denominar funcional" (O llícito Administrativo e seu Processo, Sāo Paulo: Editora Revista dos Tribunais, 1994, p. 28).

19 Edmir Netto de ARAÚJO, $O$ ilícito..., p. 56. 
disciplinares e funcionais estão descritos na Lei Orgânica da Polícia (Lei Complementar n. 207/79) e, no que não conflitar, no Estatuto dos Funcionários Públicos Civis do Estado de São Paulo (Lei 10.261/68). Como exemplos de ilícitos administrativos disciplinares e funcionais basta ver as condutas previstas nos arts. 62 e 63 da Lei Complementar n. 207/79. ${ }^{20}$

\section{4 - A penalidade Administrativa}

O desenvolvimento da atividade administrativa disciplinar desemboca-se em um determinado fim, isto é, em um factum, um resultado, que se configura por intermédio de um ato administrativo final. Esse ato administrativo se apresenta sob duas formas: i) um ato administrativo que considera o servidor público culpável e, em consequiência, é aplicada uma sanção ou penalidade administrativa; ou, ii) absolve-o da imputação administrativa que lhe foi feita. $O$ que interessa agora para este estudo é a primeira vertente: aquela que ao reconhecer a culpa em sentido amplo do acusado aplica-lhe uma penalidade administrativa.

Ontologicamente, a pena administrativa possui a mesma substância do que as penas que se vêem nas outras esferas do Direito. Aplica-se aqui o que foi dito anteriormente a respeito do direito de punir administrativo e o direito de punir penal. ${ }^{21}$ A diferença entre esses institutos jurídicos está no regime jurídico construído a partir do interesse do legislador pátrio. Igualmente, não se vê qualquer diferença de substância entre as expressões penalidade e sanção administrativa. Talvez um critério diferenciador seria a atribuição da expressão penalidade à imposição pelo órgão jurisdicional e a sanção administrativa pela Administração Pública. ${ }^{22}$ Todavia, neste trabalho as duas expressões serão utilizadas como sinônimas em razão do próprio ordenamento jurídico vigente que ora utiliza-se de uma expressão ora utiliza-se de outra.

A penalidade administrativa conceitua-se como "a sanção imposta ao funcionário faltoso, tendo por fim a correção sua, além da prevenção que sua aplicação enseja. A correção faz sentir ao autor do fato punido a incorreção do seu procedimento e a necessidade de melhorar a sua conduta. A prevenção está no sentido de que a pena procura evitar que o faltoso volte a transgredir, servindo, ainda, de exemplo, de alerta a todos os outros funcionários, mostrando-lhes as consequências da má conduta".23

Segundo a recente Lei Estadual n. 10.177/98, art. $6^{\circ}$., inciso II: "Somente a lei poderá prever infrações e prescrever sanções". Nesses termos, vê-se que tem apli-

20 Conforme mencionado, essas infrações estão previstas em lei. Reforça esse entendimento, por exemplo, o art. $6^{\circ}$., inciso $I$, da Lei n. $10.177 / 98$.

21 Nota de rodapé n. 15, p. 7.

22 Ver nesse sentido: Régis Fernandes de OLIVEIRA, Infrações e Sanções Administrativas, São Paulo: Editora Revista dos Tribunais, 1985, pp. 32 e 33.

23 Álvaro LAZZARINI, Estudos de Direito Administrativo, $2^{\star}$ ed., São Paulo: Editora Revista dos Tribunais, 1999, p. 402. 
cação o princípio do nullum poena sine lege fazendo com que as sanções administrativas somente sejam aplicadas quando previstas no ordenamento jurídico vigente.

Em respeito a esse princípio vê-se que, especificamente, em relação aos policiais civis, a própria Lei Complementar n. 207/79, em seu art. 67, apresenta o rol de penas disciplinares principais relativas à prática de uma falta administrativa, no âmbito da Polícia Civil de São Paulo. Elas são as seguintes: i) advertência; ii) repreensão; iii) multa; iv) suspensão; v) demissão; vi) demissão a bem do serviço público; e, vii) cassação de aposentadoria ou disponibilidade. As duas primeiras classificam-se com morais; a pena de multa, como pecuniária; a suspensão como profissional e as demais como expulsivas. ${ }^{24}$

À penalidade administrativa deve ser observado o regime jurídico do Direito Administrativo, especialmente, a motivação desse ato administrativo, pois somente dessa forma poderá se saber qual foi o caminho percorrido pelo agente público e, em consequiência, tornar possível o controle de legalidade sobre esse ato administrativo exarado. Ainda, deve ser ressaltada a impossibilidade de bis in idem isso é, a dupla punição administrativa sobre a mesma conduta ilícita praticada. Essa prática não é prestigiada pelo Direito pátrio, segundo os princípios da legalidade e da tipicidade. ${ }^{25}$ Todavia, isso não quer dizer que o fato praticado impossibilite a punição em outras instâncias jurídicas; essas são autônomas e, portanto, sujeitas a regimes jurídicos diversos, o que torna lícito dizer que uma falta administrativa pode configurar, entre outras, uma falta criminal, ou uma falta civil e por intermédio dessas esferas o agente sofrer as conseqüências jurídicas pertinentes. ${ }^{26}$

\section{2-O Direito Administrativo Disciplinar Adjetivo}

\section{1 - Introdução}

O ordenamento jurídico pátrio, ao adotar o princípio do Estado Democrático de Direito, consagra a divisão funcional do poder soberano estatal em legislativo, judiciário e executivo (art. $2^{\circ}$., da Constituição Federal). Pela importância que o Direito lhe reserva, o processo jurídico-estatal constitui uma garantia das pessoas em relação ao exercício do poder político estatal, desenvolvido por esses poderes, e também, torna mais clara sua atuação. Além disso, não é privativo nem se limita à processualidade judicial. Nesse sentido, o doutrinador Adolf MERKL já se manifestava em $1927 .^{27}$

24 Ver Álvaro LAZZARINI, Estudos..., 403.

25 Nesse sentido: Eduardo Garcia de ENTERRÍA e Tomás-Ramon Fernandéz, Curso de Derecho Administrativo II, cuarta edición, Madrid: Civitas, p. 183.

26 Nesse sentido, destaca-se o entendimento do mestre Wallace Paiva MARTINS JUNIOR, Probidade Administrativa, São Paulo: Editora Saraiva, 2001, p. 180.

27 Teoria general del Derecho Administrativo, México: Nacional, 1975, pp. 279-280. Atualmente, 
Por ser o responsável pela veiculação da vontade estatal o processo jurídico-estatal, em todas as suas circunstâncias, está submetido ao regime jurídico de Direito Público, que "visa a regular, precipuamente, os interesses estatais e sociais cuidando só reflexamente da conduta individual". ${ }^{28}$

A processualidade jurídico-estatal apresenta-se sob uma concepção ampla, na qual é possivel, por intermédio de um processo indutivo, verificar a existência de um núcleo essencial comum, ainda que mínimo, onde se revelam "notas predominantes da processualidade jurídica presentes em vários âmbitos em que se expressa" ${ }^{29}$ Ele é formado pelos seguintes traços que se configuram como uma constante: i) um fieri e um factum; ii) a autonomia relativa e as ligações lógico-jurídicas entre o direito material e o direito processual; iii) o necessário encadeamento sucessivo, causal, direcionado a um resultado unitário final. Em razão do objeto deste trabalho, esses traços não serão objeto de análise. O que importa tão-somente é mencioná-los e afirmar que eles estão presentes em todos os fenômenos da processualidade jurídico-estatais; em razão disso, formam uma teoria geral do processo ou, em grau mais abstrato, são dados constantes da teoria geral do direito. ${ }^{30}$

No campo específico do Direito Administrativo o fenômeno da processualidade jurídico-estatal sofre a intervenção - gerando a integração entre as normas jurídicas - das regras e princípios que são próprios dessa disciplina jurídica. Ao ser recortado num âmbito mais concreto esse fenômeno da processualidade jurídico-estatal administrativa é designado pela expressão processo administrativo.

Essa expressão, em nosso sistema jurídico, possui mais de um significado. De um lado, designa relação jurídica processual, uma vez que adquire autonomia relativa $^{31}$ do direito material envolvido e estabelece um liame jurídico entre a Administração e o Administrado ou Administrados. No mesmo plano jurídico, mas numa outra acepção, a expressão processo administrativo designa procedimento, isto é, rito processual e pressuposto objetivo de formação do ato administrativo. Enquanto rito processual, segundo a natureza do provimento administrativo final que se visa obter, ${ }^{32}$ poderá haver ou não a litigância ou a acusação em geral. Nesses termos, os ritos procedimentais que não contêm esses qualificativos são agrupados sob uma

também partilha desse entendimento o Prof. Carlos Ari SUNDFELD (A importância do procedimento administrativo, Revista de Direito Público, n. 84, São Paulo: Editora Revista dos Tribunais, 1987, p. 66).

28 Hely Lopes MEIRELLES, Direito... p. 32.

29 Odete MEDAUAR, A processualidade no direito administrativo, São Paulo: Editora Revista dos Tribunais, 1993, p. 23. Sobre a existência de um núcleo comum da processualidade, ver Romeu Felipe BACELLAR Filho (Principios... p. 53).

30 Odete MEDAUAR, A processualdiade..., p. 23.

31 Trata-se de autonomia relativa porque o direito adjetivo está a serviço do direito material e, em última análise, do Estado Democrático de Direito.

32 Ver sobre esse assunto a obra de Gilson Delgado MIRANDA, Procedimento Sumário, São Paulo Revista dos Tribunais, 2000, p. 49. 
categoria jurídica própria, denominada simples processos ${ }^{33}$ ou simples expedientes. ${ }^{34}$ Esses processos englobam os processos administrativos de provimentos meramente declaratórios, por sinal, mais comuns na esfera do Direito Administrativo.

Todavia, quando o rito contiver a litigância ou o acusado ou acusados em geral, estar-se-á diante de um processo administrativo qualificado, ao qual pode ser atribuído o nome de processo administrativo complexo. Esses englobam tão-somente os processos administrativos disciplinares, sancionatórios, e revisivos por provocação quer de um interessado, quer de qualquer administrado, por intermédio do exercício do direito de petição; eles são próprios dos provimentos ou atos administrativos de caráter disciplinar, sancionatório ou revisivo por provocação.

Para este trabalho, por evidente, interessa tratar do processo administrativo disciplinar em todos os seus sentidos e relações com os Policiais Civis do Estado de São Paulo.

\section{2 - Os processos administrativos disciplinares no âmbito da Polícia Civil do Estado de São Paulo}

O critério fundamental que diferencia os processos administrativos simples dos processos administrativos complexos é a litigância ou acusação em geral. Quando esses estão presentes o ato administrativo final poderá gerar um efeito jurídico restritivo ao direito de liberdade e de propriedade de um servidor público civil, no caso os agentes públicos pertencentes aos quadros da Polícia Civil Estadual. Nessa situação deverá ser observado o devido processo legal que se concretiza por intermédio da observância do contraditório e da ampla defesa, nos termos do art. $5^{\circ}$., incisos LIV e LV, da Constituição Federal.

Por litgância administrativa entende-se a controvérsia ou conflito de interesses entre a Administração Pública e particulares ou seus agentes públicos, ou entre esses, aqui abarcadas as pessoas físicas e jurídicas. Por isso, em face da Constituição Federal, assegura-se o contraditório e a ampla defesa, bem como os recursos a ela inerentes. $^{35}$

Em relação aos acusados em geral, vê-se o seu significado quando sobre um servidor público civil pertencente aos quadros da polícia civil do Estado de São Paulo recair qualquer imputação de conduta ou falta ilícita, capaz de gerar uma punição, espécie de restrição de direitos desse acusado. Essa expressão, acusados em geral, deve ser entendida em sentido amplo e é aplicável à situação fática em.

33 O termo simples foi adotado das afirmações do Mestre Egon BOCKMANN MOREIRA, no artigo "Processo Administrativo e o principio da eficiência", inserto no livro As Leis de Processo..., p. 334.

34 Esse termo é utilizado por Hely Lopes MEIRELLES (Direito..., p. 559).

35 O Prof. Romeu BACELLAR FILHO averba: "Perceba-se a redação do dispositivo dando realce à particula ' $e$ ' que, ao invés de configurar sinonímia, expressa conjunção aditiva" (Princípios Constitucionais..., p. 67. 
relação à pessoa física ${ }^{36}$ Essa generalidade exposta no texto constitucional justifica-se: a) primeiro, por motivo históricos, pois, antes da Constituição Federal de 1988, havia uma discussão acerca da aplicabilidade ou não da ampla defesa e do contrário nos processos administrativos, com posicionamentos de Tribunal de Justiça no sentido de inaplicabilidade; b) segundo, pelo fato de que há no ordenamento jurídico pátrio alguns processos administrativos que, apesar de não qualificarem como acusados aquelas pessoas que sofrem imputações por condutas ou omissões ilícitas, acabam possibilitando a imposição de uma penalidade administrativa. Esses processos administrativos complexos poderiam ensejar controvérsias sobre a aplicabilidade ou não do contraditório e da ampla defesa pela Administração, ao argumento de que inexistiriam acusados, mas sindicados ou qualquer outro nome que se quisesse dar.

A título de exemplo, temos a recomendação baixada pela Delegacia Geral de Polícia do Estado de São Paulo, em 14 de janeiro de 1997, que veicula a necessidade de serem observados a ampla defesa e o contraditório nas sindicâncias punitivas, isto é, aquelas que podem ensejar a aplicação de penas disciplinares principais elencadas na Lei Complementar n. 207/79.

A respeito da sindicância, vê-se que esse diploma jurídico, nos artigos 87 a 93, regula essa espécie de processo administrativo de rito simplificado. ${ }^{37}$ Ela pode ser: investigatória, assemelhando-se ao inquérito policial (art. 88 inciso I); ou punitiva, quando enseja a aplicação de uma penalidade administrativa (art. 88, inciso II). Assim que há a instauração da sindicância pela autoridade competente (art. 91 e 70) deve haver a comunicação do fato à Corregedoria da Polícia Civil e ao órgão setorial de pessoal (art. 91, parágrafo único). O prazo para a sua conclusão é de 30 dias, a contar da sua instauração, prorrogáveis por mais 30 (trinta), mediante solicitação ao Superior Hierárquico imediato (art. 92). Quando se tratar de sindicância punitiva rigorosamente deve ser observado os procedimentos insertos no art. 93 da Lei Complementar n. 207/79 e a já mencionada recomendação da Delegacia Geral da Polícia, no âmbito da Polícia Civil do Estado de São Paulo.

Uma situação que merece destaque e que não mais encontra respaldo no ordenamento vigente, salvo melhor juízo, é a possibilidade de se aplicar a pena disciplinar pelo critério da verdade sabida. O art. 90 da Lei Orgânica da Polícia do Estado de São Paulo afigura-me inconstitucional porque ele aniquila a ampla defesa na medida em que essa, para ser eficaz, exige que seja observado um momento cronológico de sua realização, isto é, ela deve ser apresentada antes que a decisão final seja proferida. Essa situação não acontece na punição pela verdade sabida. Diante dessa incompatibilidade normativa, prevalece, evidentemente, o texto constitucional.

Em relação aos processos administrativos disciplinares que contêm a acusação administrativa, vê-se que a Lei Orgânica da Polícia Civil os regula por intermédio dos artigos 89, 94 a 121. A seguir serão destacados os pontos relevantes desse fenômeno processual jurídico-estatal administrativo.

36 Nesse sentido: Odete MEDAUAR, A Processualidade..., p. 78.

37 Esses termos são adotados pela citada recomendação. 
Nene di-positivos legais estão expressos os casos em que obrigatoriamente se deve instautar os processos administrativos disciplinares (art. 89) e também as autoridades cinlinpetentes para determinarem a instauração desses processo administrativos dixciplinares (art. 94). Ao assim procederem, deverão motivar a decisão administrativa (parágrafo único, art. 94), designar o indiciado para o exercício de atividade exclusivamente burocrática até o final da apuração (alínea $a$ ) e recolher o distintivo. as armas e as algemas cedidas mediante carga (alínea $b$ ). O desenvolvimento desse processo administrativo estará a cargo da Comissão Processante Permanente ou da Comissão Especial designada pelo Delegado-Geral de Polícia (art. 95), composta por 3 Delegados de Polícia, um dos quais será seu Presidente (art. $95, \S 1^{\circ}$ ), e também a quem compete designar o secretário que será um Escrivão de Polícia (art. $95, \S 2^{\circ}$ ). Tanto em relação à sindicância como em relação aos processos administrativos disciplinares deve haver o respeito ao princípio da imparcialidade; daí ser inadmissível que qualquer desses agentes públicos estejam impedidos ou suspeitos (art. 96). ${ }^{38}$

Entre os artigos 97 ao 102, destacam-se: 1) a impossibilidade de serem decretados os efeitos da revelia, isto é, a presunção de veracidade dos fatos constantes da portaria inaugural, em face do princípio da verdade material que vigora nesses processos; ii) o maior respeito à ampla defesa ao realizar a primeira audiência para a oitiva ou interrogatório do acusado, o que revela a falta de utilidade, salvo melhor juízo, do art. 99; iii) a necessidade imperiosa de ser feita a defesa por um profissional legalmente habilitado, isto é, o Advogado. Daí a impossibilidade se nomear um bacharel em direito pura e simplesmente, conforme mencionam os arts. 101 e 102.

Os artigos 103 a 111 tratam da fase instrutória. Aqui destacam-se: i) a impossibilidade de serem realizadas provas ilícitas (art. $5^{\circ}$, inciso LVI, da Constituição Federal) tais como escutas telefônicas clandestinas, uso de detectores de mentira; ii) a impossibilidade de produção de provas protelatórias e desnecessárias (arts. 22, § $2^{\circ}$., da Lei Estadual n. 10.177/98, e art. 110 da Lei Orgânica; iii) o direito ao silêncio por parte do acusado quando do seu interrogatório (art. $5^{\circ}$. inciso LXIII, da Constituição Federal); iv) a possibilidade de realização de provas tardias em face da verdade material e da oficialidade (art. 111 da Lei Orgânica da Polícia).

$\mathrm{O}$ artigo 112 prevê a audiência do interessado antes da decisão final. Assim permite a abertura de prazo para o oferecimento das alegações finais cabendo à comissão no prazo de 10 dias apresentar o seu relatório final (art. 113). Essa atividade da Comissão é opinitiva, pois, a decisão final caberá, em regra, ao Delegado-Geral de Polícia. após a submissão do processo ao Conselho da Polícia Civil (arts. 114 e 115); quando o caso, essa decisão final caberá ao Governador ou ao Secretário da Segurança Pública (art. 70). Contra a decisão administrativa impositiva de uma penalidade administrativa poderá haver recurso por força do art. $5^{\circ}$., inciso $\mathrm{LV}$ da Constituição Federal, vigorando em todos os processos administrativos o princípio da gratuidade e a impossibilidade do reformatio in pejus. 
Inúmeras questões envolvem o Direito Administrativo Disciplinar, pois ele é casuístico e se insere num quadro teórico amplo que responde a urgente necessidade social pelas incumbências que ele suscita no trato da coisa pública.

Esse trabalho teve como objeto de estudo o Direito Administrativo Disciplinar no âmbito da Polícia Civil do Estado de São Paulo. Não se pretendeu esgotar esse tema rico e relevante para o Direito Público e suas relações intersubjetivas com a Polícia Civil e a sociedade civil. Talvez a grande novidade pelo menos para o seu autor, entre outras, tenha sido a oportunidade de ser feita uma leitura jurídica por um profissional do Direito que pertence à Administração Pública Direta do Estado de São Paulo, mas não aos quadros da Polícia Civil deste mesmo Estado. Esse fato permitiu o descobrimento de noções jurídicas importantes que se encontram no Direito posto, num âmbito específico - por exemplo, na Lei Orgânica da Polícia —, mas fundamental para se atingir a compreensão mais íntima do assunto versado.

\section{Referências Bibliotráficas}

ARAÚJO, Edmir Netto de, O Ilícito Administrativo e seu Processo, São Paulo: Editora Revista dos Tribunais, 1994.

BACELlAR FILHO, Romeu Felipe, Princípios Constitucionais do Processo Administrativo Disciplinar. São Paulo: Max Limonad, 1998.

ENTERRÍA, Eduardo García. Curso de Derecho Administrativo II, $4^{\text {a }}$ ed., Madrid: Civitas, 1997.

FIGUEIREDO, Lúcia Valle, Curso de Direito Administrativo, $3^{\mathrm{a}}$ ed., rev. e atual, São Paulo: Malheiros Editores, 1998.

LAZZARINI, Álvaro, Estudos de Direito Administrativo, $2^{\mathbf{a}}$ ed., São Paulo: Editora Revista dos Tribunais, 1999.

LUZ, Egberto Maia, Direito Administrativo Disciplinar, $2^{\mathrm{a}}$ ed., rev. e atual., São Paulo: Editora Revista dos Tribunais, 1992.

MARTINS Junior, Wallace Paiva, Probidade Administrativa, São Paulo: Editora Saraiva, 2001.

MEDAUAR, Odete, A processualidade no direito administrativo, São Paulo: Editora Revista dos Tribunais, 1993.

MEIRELLES, Hely Lopes. Direito Administrativo Brasileiro. 23. ed., São Paulo: Malheiros Editores, 1998, at. por Eurico Andrade Azevedo, Délcio Balestero Aleixo e José Emmanuel Burle Filho.

MELlo, Celso Antônio Bandeira, Curso de Direito Administrativo. 8. ed., rev., at. e ampl., São Paulo: Malheiros Editores, 1996.

2001. Curso de Direito Administrativo. 13. ed., São Paulo: Malheiros Editores,

Discricionariedade e Controle Jurisdicional. São Paulo: Malheiros Editores, 1992. 
MELLo, Oswaldo Aranha Bandeira, Princípios Gerais de Direito Administrativo, 1. ed., Rio de Janeiro: Forense, 1969, v. 1.

MERKL, Adolf, Teoria General Del Derecho Administrativo, México: Nacional, 1975.

MIRANDA, Gilson Delgado, Procedimento sumário, São Paulo: Revista dos Tribunais, 2000.

MOREIRA, Egon Bockmann, "Processo administrativo e o princípio da eficiência", As Leis de processo administrativo, coordenação de Carlos Ari SUNDFELD e Guillermo Andrés MUÑOZ, São Paulo: Malheiros Editores, 2000.

OLIVEIRA, Régis Fernandes, Infrações e Sanções Administrativas, São Paulo: Editora Revista dos Tribunais, 1985.

PIETRO, Maria Sylvia Zanella, Direito Administrativo. São Paulo: Atlas, 1999.

SUNDFELD, Carlos Ari. Direito Administrativo Ordenador, $11^{\mathbf{a}}$ ed., São Paulo: Malheiros Editores, 1997.

"A importância do procedimento administrativo", Revista de Direito Público, n. 84, São Paulo: Editora Revista dos Tribunais, 1987. 